\title{
Decent Work and The Quality of Work and Employment
}

\author{
Francis Green
}

\author{
Professor of Work and Education Economics, UCL Institute of \\ Education, London, UK.
}

GLO Research Fellow

francis.green@ucl.ac.uk

JEL codes: J01, J30, J81

Keywords: job quality, well-being, wages, insecurity, working time, work intensity, skills, discretion, social environment, physical working conditions.

\begin{abstract}
This review examines the concept of the quality of work and employment (QWE), including both 'Decent Work' and the narrower concept of 'job quality'. The key axiom is that 'quality' relates to the extent and manner in which working conditions meet people's needs from work. The review emphasises the multi-disciplinary nature of the topic. It discusses the concept's objective character, its relationship with well-being, and its link with productivity. Important measurement issues are considered, including cost, international comparability, the choice of how many indices, the treatment of inequality and the problem of discipline insularity. Some theories of the antecedents of QWE imply universal trends, while others predict differentiation across countries and regions, attributable to labour market institutions and policy. The effects on well-being and health are studied in several disciplines, including a substantial research programme in psychology. Summary trends in Europe and distributions of job quality are presented for context, including gender gaps. This description shows gradual improvement in the physical environment of work and in working time quality over the decade from 2005. Yet the distribution of job quality in several domains is not at all closely related to a country's GDP. The review concludes with a discussion of job quality policy making, and frames the ongoing research agenda.
\end{abstract}




\section{Decent Work and The Quality of Work and Employment}

\section{Introduction $^{1}$}

It was around the time of the millennium that, after decades of economic development and global growth, supra-national organizations and some national governments began calling, not just for employment measures but for 'more and better jobs'. This was an aspiration not just for higher wages, the conventional economic measure of a job's quality, but for improvement in all features of work and employment that contributed to well-being. Social scientists of several disciplines including economists, health analysts, psychologists and sociologists - had been thinking and writing about the broader aspects of work for decades, with at least some of this research placed at the service of developments in health and safety regulation and of equal opportunities policies. Now, at last, policy-influencers at the highest level were starting to take it seriously.

Most prominent among the global institutions looking to change the orientation of policy was the International Labour Organization (ILO), a branch of the United Nations. Its Director-General proclaimed that "decent work" was "the most widespread need, shared by people, families and communities in every society, and at all levels of development", and went on to announce that "the primary goal of the ILO today is to promote opportunities for women and men to obtain decent and productive work, in conditions of freedom, equity, security and human dignity" (ILO, 1999).

This bid to put work life and its quality at the heart of policy-making was closely followed by the Lisbon meeting of the European Commission in 2000, where the European Union (EU) committed itself to a new objective: "to become the most competitive and dynamic knowledge-based economy in the world capable of sustainable economic growth with more and better jobs and greater social cohesion". And, soon after, the Organization for Economic Cooperation and Development (OECD) also adopted the "more and better jobs" slogan even if, with respect to the 'better' part of the mantra, the slogan was to lack much substance until a decade later (OECD, 2003; 2017).

In subsequent years progress has been hindered by two global crises - the great recession of 2008 and recently the COVID19 pandemic - both of which put the quantity of employment at the top of the labor policy agenda, while its quality lagged behind. Advancement of understanding by academic and institutional researchers has also been limited by conceptual and measurement confusions, by lack of resources for relevant data collection, and by interest clashes between industry partners (Burchell et al. 2014). Not helpful has been the proliferation of terms.

Nevertheless, advances have been made. And, perhaps also because of its recognised deep importance, the 'quality of work and employment' (hereafter QWE) - the term covering the concepts to be clarified and discussed in this review - has emerged as an important umbrella concept in academic and policy discourse. Decent Work entered the policy mainstream with the agreement by Heads of State at the United Nations in 2015 of the 2030 Agenda for Sustainable Development, which replaced the Millennium Development Goals. Specifically, Sustainable Development Goal 8 is to "Promote sustained, inclusive and sustainable economic growth, full and productive employment and decent work for all". It is, of course, a challenging goal, at least in some parts of the world (Moen et al. 2020).

This review aims, first, to clarify key conceptual and measurement issues that have emerged and how they have been at least partially resolved (sections 1 and 2). Next, it sets out the theoretical frameworks in use for understanding QWE, which mandate an interdisciplinary approach (section 3). The review then describes briefly some of the main stylised facts about QWE across countries (section 4). Section 5 summarises; it emphasises a call to all social scientists concerned with QWE to 
address the issues from a truly multidisciplinary perspective, and considers potential future directions for QWE concepts in research and policy discourse.

\section{The Quality of Work and Employment: A Family of Concepts}

If concepts of the "quality" of work and employment are to be at the heart of a flourishing scientific literature, the first essential must be clarity in its terms. The fundamental idea behind the concepts to be discussed here is that quality is defined by whatever contributes to meeting human needs from work.

Different authors' and institutions' approaches to the concepts vary according to the units of analysis, and also by the extent of the domains included - see Table 1. "Decent Work" is the broadest concept, intended to characterise an essential aspect of life in a country or region, encompassing its jobs, its workers, the labor market and other society-level features. At the level of the worker, it foregrounds workers' rights, educational participation, and the moral argument against child labor; embracing the labor market it brings in unemployment rates and the use of social dialogue; at the level of society it includes social protection.

The phrase 'quality of work and employment' covers both 'decent work' and the narrower concept of 'job quality', which concerns those characteristics of a job, whether as an employee or in selfemployment, which are held to meet workers' needs. Earnings, for example, enables satisfaction of material needs, while the work itself can address other needs - for example, the needs for good social relationships at work, for creative purpose, meaningfulness and identity, for flexible time scheduling, and for a safe environment. The majority of the recent decades' literature has this jobcentred focus (e.g. Green 2006; Muñoz de Bustillo et al. 2011a; Holman and McClelland 2011). Similarly, Eurofound analyses job quality in many of its publications, using a theoretical and political framework of seven worker-centred domains: Earnings, Prospects, Working Time Quality, Work Intensity, Skills and Discretion, Social Environment and Physical Environment (Eurofound, 2012). There are also synonyms for job quality in circulation, including the "quality of employment" (Burchell et al. 2014), and sometimes the "quality of work and employment" (European Foundation for the Improvement of Living and Working Conditions 2002). "Working conditions" is another term in common use, with a seemingly narrower focus on just the physical environment of work, but in practice covering the same domains as job quality (Eurofound and International Labour Organization 2019).

"Quality of work" has a still narrower focus, referring to many of the domains of job quality but excluding key extrinsic features, notably earnings. This concept has its own synonyms, including "work quality" (Cooke et al. 2013), "quality of the work environment" (OECD, 2017) and "quality of work" (Gallie 2013a,b; Stiglitz et al. 2009).

The concepts of job quality promoted by the OECD, the European Trades Union Institute (ETUI) and the United Nations Economic Commission for Europe (UNECE) are similar in many respects to that of the Eurofound. However, the OECD's framework (Cazes et al. 2015) extends the domain of earnings to include national pay inequality. The ETUI and UNECE both register the fit between the individual and job as part of job quality: the ETUI include the fit between working hours and family commitments (Leschke and Watt 2008), while UNECE include the extent to which individuals' skills match the skills requirements of jobs (UNECE 2015). The UNECE framework goes one step further by also including workers' own skills, in particular their 'employability': that item stands out as seemingly inconsistent with the framework as a whole. 


\section{[TABLE 1 ABOUT HERE]}

Table 1 is not, it should be noted, a comprehensive listing of the frames that have in the past been proposed. It excludes the frame developed at the European Council's Laeken summit in 2001, which contained an incomplete and conceptually inconsistent mix of domains, was criticised in the academic literature, and in the end proved unsuitable for its purpose within the European Employment Strategy (Davoine et al 2008; Green, 2006; Muñoz de Bustillo et al. 2011a; Piasna et al. 2019). Nor does Table 1 cover the "quality of work life" frameworks that grew in the 1970s alongside and within the nascent literature on quality of life (Guest and Grote 2017): these embraced a somewhat eclectic mix of concepts but certainly included domains that now form part of the subfield of QWE studies. The Employment Conditions Employment Network (EMCONET) of the World Health Organization has also developed a concept of "fair employment" which complements the ILO's decent work framework (World Health Organization 2007).

Before moving to consider the measurement of QWE concepts, the remainder of this section addresses four salient issues surrounding them that have been at least partially if not fully resolved in recent years: the link with well-being, the distinction between the objective character of job quality and job evaluations, the importance of process, and the association with productive efficiency.

\subsection{The association with well-being}

It follows from the fundamental idea stated above that in all concepts of QWE there should be an intrinsic relationship between QWE and well-being. This relationship stands whatever theory of wellbeing might be implicitly adopted. The OECD adopt a capability-based understanding of well-being and human need (Cazes et al. 2015; Stiglitz et al 2009). Since well-being is multidimensional - being comprised of both material well-being and several quality of life dimensions -- so, it is argued, is job quality.

This association with well-being does not imply that QWE can be equated to, or measured by, workrelated well-being - a trap that has occasionally been slipped into in past literatures. However, the intrinsic link does suggest three lines of analysis.

First, taking the association as a given, the link with well-being is a potential route to validating indicators of decent work or job quality (for example, Holman 2013). This approach might be strictly empirical: an analyst in possession of a putative index of job quality or decent work, and also an acceptable indicator of well-being, can investigate if the two are linked either through univariate or multivariate correlation. Alternatively, an analyst may have recourse to a fundamental philosophical position: for example, the assumption, that more skilled labor involving greater worker control (decision latitude) is less alienating and of higher quality might be made on the basis of an accepted theory of the human labor process.

In a second line of analysis, the intrinsic link with well-being has been used in the messy business of imputing weights for multiple inputs for the creation of job quality indices: the domain weights are derived according to how well the job quality domain explains the well-being outcome of interest. Two good examples are Green, C. et al (2010) and Holman and McClelland (2011). Unfortunately, the procedure is dependent on having complete confidence in the well-being indicators. Given the range of well-being and health concepts, and the multitude of empirical measures, the link fails to avoid the need for theoretical - or, sometimes, moral - judgement about the importance of different domains.

Nevertheless, a third important, independent avenue for ongoing research - not least, for the purposes of policy advice - is to estimate the magnitude of the causal associations between 
components of job quality and health or well-being outcomes: this is the mission of a voluminous, ongoing multi-disciplinary research literature.

\subsection{The Treatment of Subjective Evaluation and Affect}

Job quality and Decent Work are objective features of jobs and nations. Relevant data are collected through multiple channels and, owing to its complexity and multidimensionality, for many aspects of job quality the most informed source of data has been the individual worker holding the job. In these cases, analysts need to be aware of the possible biases that can occur when individuals report about something close to themselves (their job), not least social esteem bias.

Workers' reports of job quality features, however, are quite different from their subjective evaluations and their emotional responses, as for example with job satisfaction or work-related wellbeing. Some analysts propose that such evaluations should be included in the concept of job quality (e.g. Findlay et al. 2013); the same proposal can crop up among practical proposals for government statistics (Taylor 2017). Do they have a case?

The proposal derives from the observation (not new) from research studies that the same job can be evaluated quite differently by different individuals - in effect, apparently weakening the link just discussed between QWE and well-being. Certain seemingly 'bad' jobs may be willingly accepted, even preferred, by workers (e.g. Findlay et al. 2013; Cooke et al. 2013). It is also a well-known, longstanding finding that workers in low quality jobs do not always report low levels of job satisfaction (Brown et al. 2012). Part of the explanation for this phenomenon is that jobs which are seemingly bad in some domains are not necessarily so terrible in all others - features such as a good working time quality may mitigate the negatives from poor pay and intensive work. But the main explanation is that workers' evaluations of their jobs depend also on their expectations and preferences. Those for whom the alternative is an even worse job might give a good evaluation of a job with generally poor quality. Nevertheless, it is the awkwardness of these occasional high satisfaction/low job quality clashes that has led to the proposal for merging job quality with well-being concepts. Including a subjective dimension inside the concept of job quality, it is argued, would enable analysts to explain workers' tolerance of bad jobs (Belardi et al. 2020).

Yet there are strong arguments against deploying such a hybrid concept, and the large majority of researchers, as well as the European Union, the OECD and the United Nations, have opted for an objective concept (see, e.g. Holman and McClelland 2011; Green 2006; Cazes et al. 2015; Eurofound and International Labour Organization 2019; OECD 2017; Osterman 2008). A wholly objective QWE concept allows in principle for comparability over time and socio-economic space, and is potentially policy-ready. Any subjective element in QWE would render over-time comparisons of evaluative judgements much more likely to be compromised by the adaptation/ habituation of the observer than over-time comparisons of objective data. Similarly, cross-cultural benchmarking of objective jobs data are informative, but cross-cultural comparisons of job satisfaction or of emotions are hard or impossible to interpret. Opting to keep with an objective concept and measure of QWE, subjective evaluations of jobs remain of value for understanding some choices and behaviour, and it continues to be of interest to understand the variation of perceptions of jobs between contexts and over the lifecourse (Belardi et al. 2020); yet this variation does not warrant ceding the objective character of QWE concepts.

Deploying an objective concept of job quality does not necessarily mean excluding the job-person fit as a component (Table 1). Both the match of a job's work-time requirements with workers' needs, and the match between job skills and worker skills are found to affect worker well-being (Allen and 
van der Velden 2001; Friedland and Price 2003). Job quality, then, depends on whether the matching process is effective. For example, part of working time quality should include the availability of flexible time schedules, whether or not particular workers take advantage of that flexibility. The needs of the average worker can vary, typically according to their family circumstances, but it is eminently possible to design good jobs that take account of worker heterogeneity.

\subsection{Is process important?}

There is a fair degree of consensus among researchers over what domains should be included within the objective concept of job quality. Kalleberg (2011), who for the most part treats job quality as an objective concept, is not alone in easily identifying the set of job characteristics upon which "most people would agree" should be included in job quality (ibid p.5). And there is considerable overlap between the domain lists proposed by the various sources listed in Table 1. Nevertheless, some variation remains, and one open question surrounds how much workers are involved (directly or indirectly) in the processes through which their jobs are determined, and at what levels.

For example, having a high level of decision latitude could be seen as valuable in itself, or because it enables the employee to achieve specific ends; similarly, the opportunity to join a recognised trades union might be valued for itself, or just in so far as the union can gain better wages and working conditions. These issues are part of the wider question: is participation, in any or all its forms, an inherent element of high job quality and decent work per se, directly meeting a need for engagement? Or is participation just a possible channel for improvement?

This is not just a debate about meta-concepts. Applying Sen's capability approach to work life implies that what matters in a job are the capabilities that are afforded for workers to achieve wellbeing and reach their agency goals. Job quality should then be conceived as including the opportunity for workers to participate in determining and shaping their work activities among a range of possibilities (Green 2006, pp13-15)). Similarly, sociology situates autonomy and the skill needed to exercise it at the heart of job quality. Distinction can be made between the right to participate in decision-making and actual participation. Actual participation is individually costly, and there is some evidence that it is less valued than the right to do so (Frey and Stutzer 2005).

Participation through social dialogue has been assumed from the start to be an integral element of decent work. Social dialogue was also included originally within Europe's discussions, but it proved difficult to find agreement between social partners about suitable indicators. The OECD, by contrast, took the position that only outcomes should count in the concept of job quality; 'procedures' such as social dialogue and regulation were not considered part of the worker experience. Because procedures were sometimes not complied with, or affected working conditions only with a lag, it was argued that they should only be used as second-best indicators where reliable outcome indicators of workers' experiences were unavailable (OECD 2017, 13-14). At the job level, the OECD include organizational participation as a resource that facilitates two-way communication with employers (OECD 2017, p. 19) - in other words, as instrumental towards the achievement of higher job quality rather than intrinsic to it.

This position may be at odds, not only with the OECD framework's conceptual root in capability theory, but also with recent findings. Observational studies of procedural fairness (Tortia 2008), and experimental studies of delegation decisions (where participants are found to pay a control premium in a delegation game - see Bartling et al. 2006), show that procedural utility is valued positively.

Across many countries the self-employed express greater job satisfaction than the employed, with a good part of the gap attributable to the additional autonomy that self-employment affords (Benz and Frey 2008). Sociologists have also long ago recognised the intrinsic value of workplace participation. In one recent study Gallie et al. (2017) found, using longitudinal evidence, that task 
discretion and participation had effects on well-being measures both directly and indirectly through their beneficial effect on working conditions. Workers do appear to intrinsically value autonomy and appreciate self-determination. The case is therefore strong that participation in the determination of work should be seen as an aspect of job quality.

Yet there remains much to be clarified. One important remaining issue concerns which forms of direct participation -- personal participation through workers' task discretion, consultative participation through channels of communication between management and workers, or representational participation through trade unions or works councils - are the essential elements of job quality. This question is most likely to be settled empirically, rather than through inward philosophizing about forms of participation and human needs. The evidence to date is thin; it is surely something for emerging work scholars to add to and develop.

\subsection{The link with productivity: work quality from the employer's perspective}

Finally, the QWE concepts being discussed should not be confused with 'work quality' as used within management literature about performance management, which refers to the quality of a piece of completed work. QWE is by definition built on the worker's needs, rather than the imperatives of employers. While this distinction might seem self-evident, the conflation of employer-derived and worker-related concepts added to confusion in early stages of the literature on QWE (Green, 2006; Burchell et al 2014). Two decades on the conflation is mainly, but not entirely, absent.

Nevertheless, two sets of questions arise. First, to what extent is an efficient and highly productive economy, with high GDP, more conducive to high job quality and/or decent work, across nations and regions? Second, and conversely, can managers and employers, opting to provide improved working conditions, expect to reap improved productivity, and if so will the increase in productivity be profitmaximizing? Both questions are important, if difficult, research topics, not least for their policy implications.

There is substance in the expectation that 'work quality' and QWE are in practice correlated. Erhel and Guergoat-Larivière (2016) find, for example, that innovation and job quality country clusters are generally well correlated across institutional regimes within Europe. Establishing causation in either direction, however, is another matter. There are specific issues surrounding the effects of QWE on firm's productivity levels. Bryson et al (2017) find, for example, that greater job satisfaction raises organizational performance; given that, better job quality should do the same. The theory of efficiency wages in economic sociology provides one possible mechanism through which higher job quality might positively affect organizational outcomes: higher wages may call forth the reciprocal gift of higher discretionary worker effort (Akerlof 1982). The subsequent empirical literature on the implications of workers' reciprocity on wage formation under conditions of incomplete contracts (where effort cannot be enforced without cost) is supportive (Fehr and Gächter 2002). Nevertheless, improved job quality typically incurs costs, which might or might not exceed the additional revenues obtained. Grote and Guest (2017) would like to use the sketchily developed evidence for the effects of 'work quality' on QWE as an additional argument for revitalising research and interventions on job quality. Yet, such a tactic will need more research on the conditions under which profitable productivity-raising strategies raise job quality, and under what conditions they have the opposite effect. 


\section{Measurement Issues}

If decent work and job quality are to be useful concepts for policy-makers and social scientists, the relevant data need to be collected, and indicators computed. Progress, however, has been patchy.

Anker (2003) is an example of an early attempt at measuring decent work, comprising indicators in many domains at multiple levels: employment opportunities, unacceptable work, adequate earnings and productive work, decent hours, work stability and security, balancing work and family life, fair treatment in employment matters, safe working environment, social protection, social dialogue, and the economic and social context of work (e.g. productivity; inflation). These were meant to be indicators for seven domains: opportunities for work, work in conditions of freedom, productive work, equity, security and dignity in work. Readers will note the conflation of concepts at this early stage in the debate. From these beginnings, Bescond et al (2003) derived a more bounded index of the "Decent Work Deficit", comprising low pay, excessive hours, unemployment, low school enrolment, youth unemployment, the male-female gap in labor force participation and the proportion without an old-age pension. Bonnet et al (2003) subscribed proposals for indices based on the idea that the most important need to be delivered by work was security. More recently, the Inter-American Development Bank devised a four-component macro index comprised of the labour force participation rate, the employment rate, the degree of labour market formality and the prevalence of jobs paying a living wage (IABD 2017). Yet while others have contributed multi-level indicators, to this day there is no "Decent Work Index" from the ILO or even a limited consensual set of indices at the national level, anything like comparable to the Human Development Index. Rather, decent work has become a banner under which the ILO can organise regular indicators and orientate its training programmes and its policy work with national governments.

Regarding job quality, although most governments have limited data, genuine progress has been made towards the possibility for statistical offices to produce transparent, theoretically grounded, feasible indicators. Pioneering in this respect has been the European Union which, via its agency Eurofound, has been running the European Working Conditions Survey (EWCS) since 1990 every five years until the present, disrupted only by the global COVID19 pandemic. The key is to be able to collect information on individual workers' experiences. As noted above, the workers' themselves are the researchers' best informants. In a minority of cases multiple job-holding can be a problem: in most surveys of work, it is people who are the sampling frames, not the jobs. With limited time available in all surveys, respondents are asked to talk only about their main job, with the consequence that the second jobs go unmeasured. In an informal economy, this issue could be more severe. Nevertheless, workers' surveys of workers about their main jobs have proved to be robust sources of data.

Once collected, individuals' data can be used to compute national and sub-group aggregates and averages. Two good handbooks are now available with advice for national statistical offices and researchers on appropriate methodologies for measuring job quality domains (UNECE 2015 ; OECD, 2017). Meanwhile in 2012 the ILO published guidelines for national statistics offices as to the relevant statistics to collect on the legal frameworks and outcomes for decent work (ILO, 2013).

Two small-scale studies worth noting have instead taken the measurement of Decent Work down to the individual level, using surveys. Webster et al (2015) devise a questionnaire, which they put to good use with a practical method for sampling vulnerable workers in three specific industries in South Africa -- security, agriculture, and hospitality. Ferraro et al. (2018) propose an eight-factor index of decent work covering the domains of decent work but through the reports of individual workers. For example, instead of recording the unemployment rate, their survey scale asks 
individuals if they think they have good opportunities to find a job. Their index is applied and validated for small samples in Portugal and Brazil.

Within Europe, the measurement of job quality in the early years of the millennium matched the conceptual confusions surrounding these concepts. At the European Council meeting at Laeken in 2001 , the agreed job quality indicators were mixed in with productivity and with unrelated gender equality indicators; job level indicators were combined with person-level indicators and labor market indicators. Subsequent negotiations reduced the list to some basic, already-existing key indicators, not even including wages (Burchell et al. 2012). By 2017, however, the European parliament had accepted the seven consistent, worker-level domains of job quality that Eurofound had proposed some years earlier. Meanwhile its survey had expanded its scope along with the European Union itself ( 28 countries in 2015) to include eight additional European countries. Other countries outside Europe followed with surveys based with varying degrees of closeness on the EWCS (the Republic of Korea, the United States, and six nations in Central America: El Salvador, Honduras, Guatemala, Nicaragua, Costa Rica, and Panama) (Eurofound and International Labour Organization 2019) . These surveys are complemented by a number of bespoke national surveys. There are long-standing nationally-representative QWE survey series in Britain, Finland, France and Sweden, and in recent years surveys have also been carried out in Argentina, Chile, Singapore and Uruguay. Not all of these are guaranteed to be repeated on a regular basis or at all.

This section reviews some key remaining general issues for the measurement of QWE concepts and how they need to be resolved: the resources challenge to extend and sustain measurement of QWE globally; the perennial problems of international comparability; the questionable attractions of the single index; how to capture inequality; and the trap of disciplinary insularity.

\subsection{Measurement Costs}

The most problematic issue is obtaining the considerable resources necessary to conduct highquality nationally-representative surveys, covering at the least a thousand respondents. In principle, it should be possible to justify the expense by the importance of QWE for peoples' lives in general and for their life satisfaction (Drobnič et al. 2010; Clark et al 2018). Yet the impetus for such data collection has not been forthcoming sufficiently regularly in most countries.

Part of the reason may be a lack of sufficient weighty pressure from social science: despite the importance of work life at some point in the lives of almost all citizens, QWE attracts disproportionately low time in general social surveys. In addition, since decent work and job quality are worker-centred, data collection is not neutral between the two sides of industry. From the employers' perspective, wages are a cost, as too are many other features of good working conditions; employers' organizations understandably do not always subscribe to data collection on job quality unless the concept is broadened to incorporate their interests in productivity. It is necessary to build coalitions among institutions and sectors with pluralist interests, and a common purpose among social scientists from a range of disciplines, to develop the case for investing adequate research resources in this area. In most developing countries these issues are magnified (though not insurmountable, see Eurofound and International Labour Organization 2019), not least by a limited capacity for mounting good quality surveys among workers in the informal sectors of the economy.

\subsection{Comparability}


Within countries the prime objective of measurement should be to assess progress over time in improving decent work or job quality; hence comparability over time in successive cross-sectional surveys is an overarching principle in designing a measurement strategy. This imperative implies keeping unchanged the questions and response scales. Where possible, the survey mode and the location of questions within surveys should also be unaltered, though the evolving environment for survey research may require flexibility and dual-mode strategies to ensure continuity. A second objective may be to test the implications of job quality theories, in which case a longitudinal component is helpful.

For supra-national organizations, however, an important additional objective is that indicators should be comparable between countries and cultures. While that objective is easier to reach for certain features such as earnings - though even here it is necessary to ensure that the same concept of earnings is compared - comparability is more problematic for scales with no universal metric, such as Likert scales that must, alongside the items themselves, be consistently translated. While some aspects of non-pay job quality can be confidently compared - for example, flexibility for workers over when to start and finish work - other cross-cultural comparisons, such as of work intensity, can be more problematic if they entail culturally-contingent terms. Eurofound devotes considerable attention to the use of the best translation protocols for its international surveys. Nevertheless, there remains an ongoing need for validation research in this area. Between developing countries the problem of comparability may be heightened by lack of consistent information on contracts and occupational status.

\subsection{Single vs multiple indices of QWE}

All researchers concur that job quality is a multi-dimensional concept. Nevertheless, there is often a desire for a single index which would summarise everything about jobs for a particular country or sub-population. Closely related to that desire is the fascination and seductive power of index rankings, which are more beguiling when unitary. Whether it should be the aim of a measurement strategy to derive a single index covering all domains of job quality is an area of disagreement among researchers.

In favor of having one composite index of job quality is the fact that one then has a singular ranking between countries or sub-groups: this clarity, it is proposed, is of political value in support of job quality policies (Muñoz de Bustillo et al. 2011a, 2011b), and complementing labour market policies based on traditional indicators such as the unemployment rate (Sehnbruch et al. 2020). A unitary overall index, it is hoped, would elevate the standing of Decent Work or of Job Quality alongside other single measures such as GDP or, more recently, the Human Development Index. Moreover, a single index based on low job quality would enable policy-makers to better focus remedies for vulnerable workers.

Against having a unitary index is the argument that job quality dimensions are quite different from each other, and that the development and monitoring of job quality policies is more likely to be aided by having indicators relevant to each area of policy or practice: for example, a wages index for minimum wage policies, a physical conditions index for health and safety policy, and a working time quality index for working hours policies. If, with a single job quality index, a policy-maker is advised that the index is higher for one group than another, that information is of no use without the followup advice that this arises because, for example, their working time quality is better - in which case, it is simpler to present the information for the indicator for working time quality in the first place. A single indicator risks obscuring the complexities of job quality and its determinants that are manifested in its multiple dimensions. 
A single index approach has the additional problem of involving a decision by the statistician about how much weight to give to each domain in the construction of the overall index. Researchers have rightly avoided trying to derive market-derived weightings from estimates of hedonic wage equations, not least from the questionable assumptions that would underpin any such approach. Typically, researchers have imposed weights that are neutral between domains, using either arithmetic or geometric averaging (Ghai 2003; deBustillo et al. 2011b; Yu 2020). An alternative that uses arithmetic methods entails setting deprivation thresholds for each domain of job quality, and summing to generate an overall index of job quality deprivation (Sehnbruch et al. 2020). Whatever weights are used, one might question whether they should be the same in different settings, especially when comparing decent work in developing and rich countries.

The case for having multiple indicators is therefore strong, but it is subject to diminishing returns: the marginal explanatory value of additional disaggregated indicators decreases and is eventually balanced by the additional cost in terms of lost clarity. Hence, most agencies and researchers have opted for a dashboard oligarchy of 'a few' key indicators matching the selected domains (see Table 1 and its references) - neither an opaque unitary index, nor a confusion of indices with tens of hardto-process numbers to watch. The ILO, however, is an exception in that it has not distilled its many decent work statistics down to a small number of domain indicators.

\subsection{Should inequality be embedded in aggregate indices?}

Whether one utilises a single index or a small dashboard of indicators, it remains to choose what summative index to use for nations or sub-groups. For the most part, analysts use the average (mean or median).

Yet there is interest too in the distribution of job quality. To meet this interest, one can supplement the average with conventional inequality measures (Green et al 2013). (This approach is exemplified below, Section 4.3). Alternatively, one can build in a distributional focus by substituting a societylevel index that captures something of both the distribution and the overall level. For example, if the focus is on 'bad jobs', one can utilise dichotomous measures based on deprivation thresholds analogous to the construction of poverty indices (Sehnbruch et al 2020). Of course, this method requires additional assumptions for the specification of those thresholds, and throws away information from the rest of the distribution which might otherwise be of use for policy purposes. To take another example, the OECD embeds inequality in its aggregate earnings measure, deploying an Atkinson index that incorporates a parameter for the 'coefficient of inequality aversion' (Cazes et al 2015). It justifies this decision from the abundant evidence for the diminishing marginal effects of earnings on well-being which, combined with a utilitarian approach to policy, implies that a more equal distribution raises social welfare. In addition it draws on evidence for inequality aversion among individuals. It follows, from this logic, that inequality could be embedded in all domains of job quality, but in practise the OECD only applies that logic to its measure of earnings quality.

\subsection{The problem of discipline insularity}

The final active measurement issue to note here is that QWE is intrinsically a multi-disciplinary concept, which draws from a wide set of theories that are relevant for understanding it at different levels. This multi-disciplinarity is accepted by the majority of those researching QWE, especially those working within Europe. It is also built into the foundations of both Decent Work and Eurofound studies of job quality research, and reflected in the measures used, which for the most part avoid disciplinary insularity. 
However, multidisciplinarity is not universally accepted by researchers. In mainstream Economics, for example, a historical tendency has been to rely exclusively on wages for its measurement of job quality, and to theorise it only within its own individualistic paradigm. Within mainstream sociology, the opposite sometimes occurs, with wages beyond some unspecified minimum not being treated as part of job quality - something that would seem odd to most economists.

Within vocational counselling psychology there has emerged a new single indicator appropriating the term "Decent Work", intended to give an individual perspective on the broader vision of work proclaimed by the ILO two decades earlier (Duffy et al. 2017). The scale is based loosely on the grandly-named 'psychology of working theory' (Duffy et al 2016), which Blustein et al (2016) use as their framework to bring a vocational psychology perspective on the concept of decent work, with emphasis on marginalized workers. The scale has been adapted and applied by psychologists outside the North American context (Masdonati et al 2019). Unfortunately, the derived scale is quite restricted in its range of domains. It comprises the following factors: physically and interpersonally safe working conditions, access to health care, adequate compensation, hours that allow free time and rest, organizational values that complement family and social values. While these domains are similar to some of those already in use in much of the European literature, they curiously omit social support, work intensity/demand overload, autonomy and workers' prospects through promotion and security. Wages above a subjectively-defined 'adequate' level are not conceived as adding to need satisfaction - with no apparent justification. These basic omissions, which pose significant limitations given the abundant evidence relating them to well-being, arguably stem from the unidisciplinary perspective.

\section{Theoretical Perspectives and the State of the Evidence on QWE}

Not only in its measurement, QWE is a topic that inherently calls for an engaged theoretical multidisciplinarity. This section briefly outlines the frameworks which authors from different disciplines have deployed to help them understand $Q W E$, including both the drivers of the trends and variations in QWE, and the effects of QWE upon human well-being and need satisfaction.

\subsection{Antecedents of Quality of Work and Employment}

How can social science frame the origins of decent work and the quality of work and employment?

Field (2003) begins with the conventional macroeconomic theory of economic growth. In this, technical change leads to growth and rising labor productivity, allowing the 'decent work frontier' (the short-run trade-off between the quantity and quality of jobs) to expand over time. In modern theories of economic growth, technical change is envisaged to be endogenous, able to be influenced by a more educated and knowledgeable workforce. International trade and multinational production are expected to ensure that the technologies spread to become universal in the long term, and so there is predicted to emerge a universal global pattern of change in the quality of work and employment. Supplementing this idea of economic growth being the central driver, the non-wage domains of QWE are conceived as elements in each worker's utility function, to which a compensating wage premium or deficit would be attached, determined in a competitive market (Rosen, 1986).

This mainstream economics perspective is paralleled by similarly universal theories of growth and societal change in some sociological literatures (Gallie, 2007b). The consequence is either an optimistic or a pessimistic expectation about the long term trend in job quality, depending on the 
understanding of technical and organizational change. In the more widely-held optimistic interpretation, there would be a positive complementarity between economic growth and decent work, especially in developing countries. In the pessimistic, neo-Marxian interpretation, the expected trend is for reducing job quality, as employers seek to increase their control over the labor process and their bargaining power over labor.

In contrast, other sociologists and heterodox economic theorists stress the importance of institutions (considered broadly) in affecting job quality, and hence the expectation that there would be varying patterns and trends of QWE across and within countries and 'institutional regimes'. For the United States, Kalleberg (2011) traces the dismantling after 1970 of the post-war settlement between capital and labor, citing the processes of deregulation, globalization and technical change, alongside later neo-liberal policies of privatization and financialization. Such processes would by themselves be expected to diminish the relative power of labor, as indicated in aggregate by falling wage shares in national income (ILO and OECD 2015). However, they are balanced by economic growth which, if it raises labor productivity fast enough relative to the falling wage share, would lead to increased job quality. Hence, the pattern of change in wages and all other domains of job quality is an open empirical question which needs to be monitored.

QWE is also expected to vary between countries because institutions, orientations to labor markets and job regulation differ notably among different 'regimes' (Gallie, 2007a, 2007b). According to production regime theory, Coordinated Market Economies (CMEs) constituted a quite different 'variety of capitalism' from Liberal Market Economies (LMEs), in respect of the firm's coordination problems in training, industrial relations, corporate governance, the cooperation of their employees, and inter-firm relations. CMEs were expected to generate jobs with a higher trajectory of job quality than LMEs. According to employment regime theory, by contrast, the key variable was the balance of power resources. The theory identifies three ideal types: inclusive regimes (Nordic countries), dualist regimes (epitomised by Germany) and market regimes (similar to LMEs, the UK and Ireland being the European exemplars). In employment regime theory, job quality is again expected to be highest in inclusive regimes, not least because of the greater prominence of quality of work life policies. In dualist countries there is expected to be a greater degree of polarization in job quality between protected jobs and the more precarious jobs of vulnerable workers. Empirically, a number of studies have examined QWE across countries or clusters of countries. While the high average level, and the low inequality of job quality in Nordic countries is confirmed, especially but not only in respect of task discretion, these studies find that much of the country-level variation does not fit all that well into any simple regime classification (Esser and Olsen 2012; Holman 2013; Davoine et al 2008; Gallie, 2013b; Green et al 2013).

Within countries, the effects on QWE and decent work of mode of production, employment regulations, labor standards and labor market institutions are covered in a number of studies. Trades union effects on non-wage job quality are discussed by Bryson and Green (2015). Applications are found especially in the study of marginalised workers such as those in domestic work (Blackett and Kone-Silue 2019). Key problematic issues have been the regulatory enforcement of labor standards (Bensusan 2009), and the constraints imposed on the decent work agenda. The constraints arise from power asymmetries between local actors (Arko 2019), from the prevalence of neo-liberal orientations to policy-making (Lee and McCann 2011), and from the growth of global value chains (Marshall 2013). Many of these studies are ultimately concerned with the gap between the job quality of vulnerable workers and others in each society. An individual-level theoretical approach to the study of QWL which focuses on marginalised workers is the perspective of vocational psychology (di Fabio and Maree 2016; Duffy et al. 2016). In this approach, while economic constraints and marginalization are conceived as holding back the formation and experience of decent work, these 
can be moderated by individual psychological factors, including a pro-active personality, work volition (the capacity to make occupational choices) and perceived social support.

Rather than examining job quality or decent work as a whole, much of the literature consists of studies of specific domains, each with their own proposed set of drivers. Examples are Venn et al (2016), covering the factors underpinning trends in working time quality in Australia; or Green et al (2021) for trends in work intensity in Britain. There are countless studies of earnings trends around the world, especially focusing on wage dispersion, and many which focus on institutional determinants including union bargaining.

The dominant general issue pervading many of the studies is the extent to which there is an ongoing tendency towards bifurcation of job quality between socio-economic groups within countries, whether defined by jobs - such as between formal and informal sectors (Combarnous and Deguilhem 2019) or between tasks that can and cannot be automated (Autor et al 2003) - or by demographics. Precarious scheduling practices, for example, have been found to be a significant site for racial inequality in the United States (Storer et al. 2020). Gender gaps in QWE are especially relevant: inequalities and differences between the sexes, and imbalanced power, underpin varying work needs of men and women, and differences in the extent to which those needs are met in the presence of workplace discrimination. Sometimes the gender wage gap is included among QWE indicators (as in Europe in the case of the now-obsolete Laeken indicators, or as in the case of the Decent Work indicators in ILO (2013)). Gender mainstreaming is an important part of the work of Eurofound. Its publications focus on monitoring this axis of polarization, and systematic differences are found between the job quality experienced by men and women. The gender wage gap favouring men is well-known and ubiquitous, though varies in magnitude across nations. Work intensity is also found to be higher for women than for men in some countries (Gorman and Kmec 2007). In other domains, however, job quality is often found to be higher for women, such as with Working Time Quality (with men more likely to work excessively long hours), and the Physical Environment (with men exposed to more physical risks) (Eurofound 2017).

\subsection{The effects of QWE on well-being}

From its very definition, in terms of satisfying needs from work, there is an intrinsic theoretical association of QWE with the health and well-being of workers and their families. How do the social sciences frame and study this link?

Some studies have explored the relationship between decent work and aggregate indicators of welfare - either national income per capita or the Human Development Index. The typical finding is that there is a positive but loose relationship. For example Ahmed (2003) finds, in a cross-section of 38 countries, that there is a negative, if imprecise relationship between a measure of the decent work deficit and a country's per capita GDP and also its Human Development Index; see also Green et al. (2013) for evidence of a similar relationship across Europe. However, this relationship could not be construed as causal in either direction. Is it higher growth that permits more decent work, or vice versa? For an example of an in-country analysis of the link between decent work and economic growth, see Farne and Vergera (2015) for Columbia, though the same issue arises as to the direction of causation. Not all studies concur, however, that there is any relationship at all between economic growth and decent work: Bianchi and de Man (2020) question from a political economy perspective the social justice and inequalities surrounding a growth-driven model for the tourism industry; while Moktan $(2016 ; 2019)$ finds, using some of ILO's key decent work categories (employment opportunity, social security and social dialogue), that growth in India between 1993-94 and 2011-12 coincided with a mixed and ambiguous trend in employment quality. 
The relationship between job quality and individual well-being, by contrast, is at the centre of a substantial ongoing literature. Eurofound (2019) summarises links between QWE indicators and a range of health problems. Within economics, a positive link is assumed in labor supply theory, and the assumption of diminishing returns within the utility function is sufficient to yield well-attested behavioural predictions. In recent decades, direct links between elements of job quality and wellbeing measures have been studied, both within economics and in sociology. Using the General Social Survey in the United States, Horowitz (2016) finds positive links between several elements of QWE (task discretion, monetary compensation, job security, low work intensity, safe working conditions) and general subjective well-being. Other examples among many include: Green (2004) for work intensity; Okay-Somerville and Scholarios (2013) for skills utilization; Gallie (2013a) for direct participation; Caroli and Godard (2016) for job security; Collischon (2017) for pay. For some elements of some QWE indicators, the connection with worker well-being hardly needs establishing - an example is the prevalence of harassment or violence in the workplace (Eurofound, 2017, p. 64).

In practice, most research on the QWE/well-being link has been undertaken in small-scale studies within the field of occupational psychology. Two main theories, both of which find non-linear and moderated relationships between QWE and well-being, have dominated the discourse: the 'demand-control' model (Karasek and Theorell 1990), and the 'effort-reward imbalance theory' (Siegrist 1996). In the demand-control model the negative effects of high job demands on mental and physical well-being can be ameliorated in situations where workers are able to exercise a high degree of control ('decision latitude') over their work. Moreover, it is argued that high decision latitude is especially salient when the demands were excessive. Thus jobs could be categorised into four types: high strain (high demands/low decision latitude), 'passive' (low demands/low decision latitude), 'active' (high demands/high decision latitude) and 'low strain' (low demands/high decision latitude). While subsequent studies have found only partial empirical confirmation for this theory (Häusser et al. 2010), the model has also been supplemented by the theory that a high level of social support in the workplace - which could be from colleagues or supervisors - would also moderate negative effects on workers' health (Parkes et al 1994). In effort-reward imbalance theory, it is argued that humans have evolved a fundamental need for reciprocity and social justice, and that consequently health and well-being are compromised when there is a lack of balance between workers' efforts and their rewards. The consequences of imbalance are argued to be an enhanced risk of depression and of ischemic heart disease. For a recent update, see Siegrist (2017). The job demands-resources model (Bakker and Demerouti 2007) generalises and adds to these approaches in the most comprehensive model so far of the association between QWE and health. The 'demands' are interpreted broadly to include physical, psychological, social or organizational factors that require effort and skills; 'resources' include the autonomy, support and feedback afforded by the job. The demands and resources interact in both positive and negative ways to affect the strains of the job and the worker's motivation.

The large majority of these studies in all disciplines are observational rather than experimental, and utilise only cross-section data - usually, in the case of psychology, with relatively small if welldefined samples. Only in a small minority of studies is there an attempt to utilise quasi-experimental methods, or convincing instrumental variables (e.g. Caroli and Godard, 2016). There remains much to be done in establishing the magnitude of causal job quality effects on different aspects of health and well-being.

Finally, one aspect of job-related well-being is now posing interesting questions for QWE studies: the concept of meaningful work (Spencer 2015; Yeoman et al 2019) - defined as work activities that are considered purposeful and worthwhile. For some writers, it is taken as self-evident that decent work is meaningful. Thus di Fabio and Maree (2016, p. 9) write: "Decent work helps all workers attain a sense of self-respect and dignity, experience freedom and security in the workplace, and (as far as 
possible) is afforded the opportunity to choose and execute productive, meaningful and fulfilling work ...". One might indeed argue that the opportunity afforded by a job to do meaningful work should be included as an aspect of job quality (Mira 2021). Assuredly, doing meaningful work can be regarded as an intrinsic aspect of eudaimonic well-being, satisfying an innate need for selfdetermination; and whether a worker is fortunate to be doing so is associated with certain job quality domains, including autonomy, income, and the prospects for advancement or insecurity. Nevertheless, as with other well-being indicators, personal characteristics - in particular, competence - also figure importantly in the determination of meaning. Subjective indicators of work meaningfulness have been shown to be predictive of worker behaviour (Nikolova and Cnossen, 2020). Issues remain, however, as to how this fundamental aspect of work-related well-being can be consistently measured. That a lack of meaningfulness is keenly felt, at least by a minority, is attested by the social nerve recently touched by the concept of 'bullshit jobs' (Graeber 2013; 2019). A rich research agenda beckons, surrounding the role that policies on QWE could play in enabling the conditions for workers to find more meaning in their work life.

\section{Trends in the Quality of Work and Employment}

To set the literature surrounding decent work and the quality of work and employment in context, this section presents some international indices of QWE for comparison across countries and, to a limited extent, over time.

Information about trends in Decent Work is, unfortunately, too scarce to come to any general conclusions about trends. Some studies of Decent Work in individual countries present useful analyses of specific indicators (e.g. Moktan 2016). But the absence of an established small number of comprehensive indicators of Decent Work appears to have prevented analysts so far from addressing important questions about the general direction of decent work in the modern era. For the specific context of Europe, however, the data on QWE collected by Eurofound can be deployed. The presentation uses the seven domains of job quality adopted by European Parliament. The intention is neither to be comprehensive, nor to test the theories outlined above. Rather, it is to illustrate some prevailing patterns with available, national-level QWE indicators.

\subsection{The Trend of Job Quality in Europe.}

The trends in the Physical Environment for work across an aggregate of all 28 countries in (or joining) the European Union between 2005 and 2015 are distinctly positive (Eurofound, 2017). The index rose significantly from 82 to 84 , reflecting reductions in the prevalence of cigarette smoke and other health hazards (such as vibrating tools). Almost certainly the cut in tobacco smoke was in part due to the tightened EU-wide regulations surrounding smoking in the workplace. In 2005 some 20 percent of European workers were exposed at least a quarter of the time to tobacco smoke; by 2015 this proportion had come down to 9 percent. The average improvement across Europe is, however, by no means universal. While Greece and Portugal each showed a 7-point increase, there was virtually no change over the decade in, for example, Romania or in Ireland. There is statistically significant improvement in many countries. Yet the changes reflected by the indices are nowhere rapid or dramatic: compare the above changes with the 2015 standard deviation of the Physical Environment index -15.1. Job quality evolves quite slowly, 
There was also a distinct improvement in the Working Time Quality index (covering excessive hours, and unsocial and inflexible hours) from 82 to 84 points, driven in this case by a reduction in the proportion of workers working long working weeks (over 48 hours) from 19 percent in 2005 to 16 percent in 2015. Also improving was the Skills and Discretion index (covering a combination of job complexity and decision latitude), from 62 to 66 . There is no evidence of significant aggregate change in the Work Intensity index over this period. Yet, again, these Europe-wide generalisations normally hide opposing trends (Green et al. 2013), and one should not assume that countries are converging.

The relatively slow evolution of job quality indices within individual countries suggests the need to be wary of unsubstantiated claims of 'rapid' change in job quality; and that therefore it is normally sufficient to monitor change every few years, rather than annually. That said, greater change might be expected during the pandemic emergency consequent upon widespread lockdowns, enforced home working, and increased insecurity.

\subsection{Cross-country differences in average job quality}

To begin to summarise the distribution of QWE across countries, Table 2 shows the mean level of job quality according to the seven domains, sourced from the 2015 European Working Conditions Survey.

From the bottom line, it can be seen that the variation in each of the job quality indicators across this immensely differentiated European sample, is strongly associated with an indicator of job-related well-being, namely 'satisfaction with working conditions'. While the bare associations are very far from being causal estimates of job quality policies, they reinforce once again the potentially enormous importance of QWE studies for improving lives. Taken together the job quality indicators account for 26 percent of the overall variance in workers' satisfaction with working conditions. Considering that there will be several other factors entering into workers' perceptions of their satisfaction - including their norms and expectations as well as their personal characteristics - this is a notable proportion, associated just with QWE.

There is considerable variation in average job quality across countries, according to all domains. In the case of Prospects, Working Time Quality, Work Intensity and Skills \& Discretion, the inter-country range of the means is of the order of one standard deviation of the overall distribution. In the case of earnings the inter-country range is much greater, more than twice the overall standard deviation, while in the case of the Social Environment index (covering both positive indicators of support and negative indicators of abuse, bullying or harassment) and the Physical Environment index of work (covering posture-related, ambient and biological or chemical hazards) the inter-country range is smaller, approximately two-thirds of the overall standard deviation. Note that the tables cannot be used to compare measures of overall inequality between domains, since the indices are composed of different metrics.

How far does this inter-country range in job quality match the range of per capita GDP across nations? Figure 1 provides a simple visual answer, using a scatter plot of the average job quality indicators against GDP per capita. Earnings, Prospects and Skills \& Discretion are indeed positively related as expected across countries with GDP, but the association is far from close. Even for the case of earnings - where one might expect to find the closest relationship - there are outliers such as Switzerland where earnings are higher than would be predicted from per capita GDP. Consistent with the small comparative job quality literature, Skills and Discretion is relatively high in Norway in 2015, as one would expect of one of the Nordic countries (e.g. Gallie 2007c ; Holman 2013; Green et al 
2013). Yet it is also high in Finland, another Nordic country, despite its much lower degree of affluence. France also surprises: despite being one of the more affluent countries, with above average earnings, its workers experience lower than average job quality in the domains of Work Intensity, Social Environment and the Physical Environment.

With Physical Environment and Working Time Quality, there are a few low-income countries whose workers experience low average job quality. Turkey, for example, has a low-quality Physical Environment for work as well as a relatively low GDP per capita; Albania, also poor in terms of GDP, has very low Working Time Quality. Nevertheless, above the lowest levels, there is no strong relationship between these elements of job quality and per capita GDP. An opposite pattern is found for Work Intensity: all the low Work Intensity countries (thus high quality in this domain -- Latvia is the best) have a low GDP per capita, but there is no obvious positive or negative relationship beyond that. As for Social Environment at work, where Bulgaria and Portugal share top spot, France the bottom spot, there is absolutely no discernible relationship with GDP per capita.

In short, contrary to the expectation of Field (2003) in the early thinking about decent work, good job quality is by no means just a reflection of affluence. By the same token, one can infer that policies for the improvement of job quality need not be co-terminous with policies for economic growth.

[FIGURE 1 ABOUT HERE]

[TABLE 2 ABOUT HERE]

\subsection{Cross-country differences in job quality inequality.}

As well as the mean, also important is the inequality of job quality within countries. In order to highlight the particular problem of 'bad jobs', Table 3 focuses on how job quality at the $10^{\text {th }}$ percentile compares with that at the median. A high level of the median-to- $10^{\text {th }}$ percentile gap in a country suggests that those at the bottom are in especially bad jobs. Consistent with studies on earlier years some Nordic countries have relatively low inequality for some domains of job quality - for example, Norway has among the lowest inequality levels for Working Time Quality, Skills and Discretion, Physical Environment. Yet Denmark is quite varied, having high earnings inequality but low inequality on Skills and Discretion and Physical Environment. More generally, it turns out that countries that are, compared to other countries, relatively unequal in one dimension are not especially unequal in other dimensions of job quality. Indeed, countries that have high earnings inequality tend on average to have low inequality in their Physical Work Environment (the Spearman rank correlation coefficient is $-0.30)$.

\section{[TABLE 3 ABOUT HERE]}

\subsection{Gender gaps in job quality}

As noted above, a key dimension of inequality is the gender gap in job quality. The ubiquity of the gender pay gap is well-known and widely studied. Gender gaps in other dimensions of job quality, however, have a complex pattern, including intersections with ethnicity, age and social class, and may vary across countries.

Table 4 shows the average gender gap for all dimensions across European countries. The gap in monthly earnings is a product of underlying gaps in both hours and the hourly wage rate. It is shown to be significantly negative (women's earnings less than men's) in all countries but North Macedonia. The Prospects indicator (covering both insecurities and advancement prospects) shows no significant difference between women and men in most countries; women's prospects were worse than 
men's in five countries, better in two. With respect to Working Time Quality, women's job quality was better than men's in all countries except Denmark where there was no significant difference. Given prevailing gender differences in domestic work and care responsibilities, this pattern is as expected. Contra some earlier studies, the Work Intensity indicator is lower for women than for men in eight countries, though it is higher in three Scandinavian countries (Finland, Denmark and Sweden). For most of Europe, Work Intensity is not significantly different between women and men. A gender gap for the Skills and Discretion indicator is found in only eight countries, six of which show women in jobs with lower skills and discretion, Greece being the stand-out example.

Women's jobs have lower Social Environment indicators in eight countries, with notably richer countries - France, Belgium, Finland and Luxembourg - showing some of the largest gender gaps. Finally, the Physical Environment index is systematically higher for women in all countries except Denmark (where the difference is small and insignificant).

Part of the ongoing QWE research agenda could be expected to focus on an understanding of how these patterns and gaps evolve in different countries and regions.

\section{Summary and the Future for QWE Studies}

The study of QWE has progressed conceptually, theoretically and empirically over the last two decades, motivated and justified by its contribution to the understanding of human welfare.

The key axiom for the study of the quality of work and employment is that 'quality' relates to the extent and manner in which working conditions meet workers' needs from work. This idea enables the conceptual clarity, necessary for an adequate discussion of the theoretical, measurement and empirical issues. The 'quality of work and employment' is then used as an umbrella term to cover both 'Decent Work' - a society-level concept - and 'job quality' which is a set of features about individual jobs. The discussion has emphasised that job quality is an objective and multi-dimensional concept, for which indicators are available. Subjective evaluations of jobs - such as job satisfaction or work-related well-being - are also properly to be studied but they should not be conflated with job quality. Open conceptual issues do, however, remain, one of which concerns what forms of participation should be seen as intrinsic features of job quality.

There has also been progress in the development of measurement protocols and job quality indicators. International comparability is an important objective for measurement, and most agencies have settled on the advantages of having a few indices covering the important domains, rather than either one opaque index of job quality or very many measures. The review has emphasised the importance of multi-disciplinarity for achieving further progress on measurement. A multidisciplinary approach is also needed to study the antecedents of $Q W E$, including the potential macroeconomic drivers for change and the institutional factors affecting differentiation between countries and polarisation within them. The theory is contested between those expecting long-term improvement or its opposite, and between those expecting systematic differentiation between countries and others expecting universal, hence convergent tendencies. There is also a huge research agenda for occupational psychologists, health analysts, sociologists and even economists, being devoted to understanding the consequences of job quality variations - especially of poor quality jobs - for workers' health and well-being.

The review summed up the broad pattern of change in some elements of job quality in Europe as a whole, where the best data is available. Notwithstanding the temptation of commentators the world over to always view changes as 'rapid', the evolution in most job quality domains is quite slow. Some 
improvements were logged in respect of the physical work environment, working time quality and skills being used in European workplaces. Nevertheless, there remained large differences between countries in all the main domains of job quality; several domains do not correlate with countries' affluence as measured by per capita GDP. There are also substantive and variable levels of job quality inequality within countries. Gender gaps are an important axis of differentiation, with the gender pay advantage for men almost universal, while for Working Time Quality and the Physical Environment the gap is positive for women in most countries; and in other domains the gap varies in sign between countries.

Both between- and within-country variation in job quality, especially in the prevalence of bad jobs, form a proper space for regulation and other multi-level interventions. A continued development of the field of QWE studies is therefore now needed in support of employment policy around the world.

The "Decent Work Agenda" has become central to the ILO's mission, informing its activities in developing countries and its links with other organizations. The concept of Decent Work is used as a lens through which country reports are framed, determining the domains against which progress in particular countries or sectors is broadly assessed. ILO instruments drawn from the Decent Work Agenda began to figure in US-EU trade negotiations (Peels and Fino 2015). Within the United Nations, Decent Work has become incorporated into the Sustainable Development Goals (SDG8) for 2030. Decent Work links also with other agendas, including those for combating climate change (Pollin 2020), gender equality (Bletsas and Charlesworth 2013), and human rights (Frey and Macnaughton 2016). According to Hughes and Haworth (2011), its embrace of the Decent Work Agenda enhanced ILO's status as a major international agency for development.

Some influence can also be traced on other trans-national organizations. Two cases in point are the World Bank and the World Health Organization. However, this influence has been limited by the perception that the agenda lacks a sufficient evidence base except in specific areas such as the proscription of child labor (di Ruggiero et al. 2014). A third is the G20: 'We need jobs. But not just any jobs' declared the OECD Secretary General at the G20 conference of employment ministers in Ankara in 2015. The conference endorsed a framework for promoting job quality loosely adapted by the ILO and OECD from their own separate frameworks, emphasising the quality of earnings, labour market security and occupational health and safety. Yet job quality has not been prominent in subsequent $\mathrm{G} 20$ gatherings.

Employment policy is also a potentially important part of the European Union's engagement with member state governments, via the European Employment Strategy. It was hoped, following the Lisbon conference in 2000, that QWE would become a significant part of that strategy, complementing the emphasis on employment and unemployment rates. However, QWE objectives at the EU level failed to filter down much to national policies, and were marginalised in the reformation of the strategy in 2005 (Smith et al 2008). The conceptual confusions had not helped and, despite the conceptual and empirical progress that has since been made, job quality has yet to become a central part of this process. It might yet become so. Eurostat now publishes regular QWE statistics, using the UNECE framework of domains. The relevance of QWE for the health of European citizens has been enough to sustain the issue in the European parliament (European Parliament 2017), and to support the ongoing expense of collecting QWE data from all European Union nations. A major constraint, again, has been the political conflict between stakeholders with differing interests, which has precluded the displacement or revision of the overall policy narrative favouring employment flexibility and deregulation (Piasna et al. 2019). To date, no QWE indicators have achieved anything like the equivalent acceptance and usage as, for example, the Human 
Development Index for nations, or the Big Five personality indicators (Burchell et al.; Piasna et al 2017).

Within nations the development of job quality policies is often fragmented, with insufficient consensus on an overall frame that would define improvement. The problem is often confounded by a gulf between scholars and policy-makers, wherein the former show too little engagement with policy design, the latter a lack of conceptual vision. Yet, looking to the future, the aspiration for improved quality of work and employment, captured in the 'more and better jobs' mantra, survives. It does so because both policy-makers and scholars worldwide acknowledge that QWE matters substantially for human well-being (Stiglitz et al 2009). If ever, with the onset of artificial intelligence, there were to be an affluent society where all could be afforded a basic income, the quality of work could assume even more importance. For now, QWE is recognised as an essential component of quality of life, and the impetus towards embedding quality of life and other well-being measures in public policy will help to sustain interest in QWE, despite the slow progress in developing this subfield. Also accepted is the need to go beyond just the wage rate, the traditional indicator of job quality. QWE indicators collectively do far better than wages alone in accounting for health and wellbeing, and of how far work is ultimately meeting people's needs.

An understanding of the political drivers and constraints surrounding the formation and implementation of job quality policies seems likely to be an important focus for future research. A recent example is Cooke et al (2019), which illustrates the importance of the cultural and industrial relations contexts in shaping the enactment and outcomes of Decent Work policies in China. More generally, scholars have a task in front of them to secure the knowledge base in this emerging subfield of study. There is much to be done, still, in understanding the drivers of change in job quality and its component domains. There is a scarcity, too, of research on policy and organisational interventions: Guest and Grote (2017) argue forcefully that this should be an essential component of a renewed QWE agenda. The effects of job quality on health and well-being, though already a substantial literature, awaits enriching for a number of domains of job quality, and is generally in need of methodological strengthening away from its considerable reliance on single cross-section observational studies. While there has been progress in developing something approaching a consensus over the concepts that constitute job quality, and in the need for an objective approach while maintaining a close relationship with well-being and health scholarship, further creative work is needed for the refinement of measurement protocols suitable for different empirical contexts, including short-form indicators of longer scales that might be used for national surveys with scarce interview times (Felstead et al. 2019). Added to these tasks will be the necessity to take on board the changes in work that may be being stimulated by the COVID-19 pandemic (Fana et al 2020).

Above all, to pursue this agenda it will be important to promote and sustain an interdisciplinary orientation to the subject. New generations of QWE scholars, from whatever social science discipline they emerge, must read, build on, criticise and engage with what is being said by those in other disciplines. Coming at it from multiple directions, scholars should find it easier to press further the importance of the quality of work and employment within the context of mainstream social science, to argue for sufficient funding and to claim regular, adequate space in general social surveys with which to better study this central aspect of people's lives. Around the world, the quality of work and employment is more important for the quality of life in general than an independent observer might guess from the amount of social science research funding devoted to it. This imbalance remains, two decades after the ILO Director General's declaration that decent work was the world's most widespread need. 


\section{References}

Ahmed I (2003) Decent work and human development. International Labour Review 142(2):263-71.

Akerlof G A (1982) Labor Contracts as Partial Gift Exchange. Quarterly Journal of Economics 97(4), 543-69.

Allen J, van der Velden R (2001) "Educational mismatches versus skill mismatches: effects on wages, job satisfaction, and on-the-job search." Oxford Economic Papers 53(3): 434-452.

Anker R, Chernyshev I, Egger P, Mehran F, Ritter J A (2003) Measuring decent work with statistical indicators. International Labour Review 142(2): 147-177.

Arko B (2019) Understanding power asymmetry in participatory development spaces: Insights from Ghana's Decent Work Programme. Regional Studies Regional Science, 6(1): 399-404.

Autor D H, Levy F, Murnane R J (2003) The skill content of recent technological change: An empirical exploration. Quarterly Journal of Economics, 118(4): 1279-1333.

Bakker A B, Demerouti E (2007) The Job Demands-Resources model: State of the art. Journal of Managerial Psychology 22: 309-328

Bartling, B., E. Fehr and H. Herz. (2014) The Intrinsic Value of Decision Rights. Econometrica 82, 2005 $-2039$.

Bensusan G (2009) Labor Standards and Quality of Employment in Latin America. Perfiles Latinoamericanos, 17(34): 13-49.

Benz M, Frey B S (2008) The value of doing what you like: Evidence from the self-employed in 23 countries. Journal of Economic Behavior \& Organization, 68: 445-455.

Bianchi R V, de Man F (2020 online) Tourism, inclusive growth and decent work: a political economy critique. Journal of Sustainable Tourism. DOI: 10.1080/09669582.2020.1730862

Blackett A, Kone-Silue A (2019) Innovative approaches to regulating decent work for domestic workers in Cote d'Ivoire: Labour administration and the judiciary under a general labour code. International Labour Review, 158(1): 37-61.

Bletsas A, Charlesworth S (2013) "Gender Equality and Decent Work in Australia." Australian Journal of Political Science 48(1): 44-56.

Bonnet F, Figueiredo J B, Standing G (2003) A family of decent work indexes. International Labour Review 142(2): 213-238.

Brown A, Charlwood A, Spencer D A (2012) Not all that it might seem: why job satisfaction is worth studying despite it being a poor summary measure of job quality. Work Employment and Society 26(6): 1007-1018.

Bryson A, Green F (2015) Unions and job quality. In Green F, Felstead F and Gallie D (eds) Unequal Britain At Work. The Evolution and Distribution of Job Quality. Oxford, Oxford University Press: 130146.

Burchell B, Sehnbruch K, Piasna A, Agloni N (2014) The quality of employment and decent work: definitions, methodologies, and ongoing debates. Cambridge Journal of Economics 38(2): 459-477.

Caroli E, Godard M (2016) Does job insecurity deteriorate health? Health Economics. 25(2), 131-147. 
Cazes S, Hijzen A, Saint-Martin A (2015) Measuring and Assessing Job Quality: The OECD Job Quality Framework, OECD Social, Employment and Migration Working Papers, No. 174, OECD Publishing, Paris.

Clark A E, Flèche S, Layard, R, Powdthavee N, Ward, G. (2018). The Origins of Happiness. Princeton, NJ: Princeton University Press.

Collischon M (2019) Relative Pay, Rank and Happiness: A Comparison Between Genders and Partand Full-Time Employees. Journal of Happiness Studies 20: 67-80.

Combarnous F and Deguilhem T (2019) Urban labour market revisited: Why quality of employment matters in Bogota. Revue D'Economie Regionale Et Urbaine (2): 283-316.

Cooke F L, Xu J, Bian H (2019) The prospect of decent work, decent industrial relations and decent social relations in China: towards a multi-level and multi-disciplinary approach. International Journal of Human Resource Management 30(1): 122-155.

Cooke G B, Donaghey J, Zeytinoglu I U (2013) The nuanced nature of work quality: Evidence from rural Newfoundland and Ireland. Human Relations 66(4): 503-527.

Davoine L, Erhel C, Guergoat-Larivière M (2008) A Taxonomy of European Labour Markets Using Quality Indicators: Final report for the European Commission. Rapport de recherche du Centre dEtudes de IEmploi n45. https://halshs.archives-ouvertes.fr/halshs-00317280

Di Fabio A, Maree J G. 2016. Using a Transdisciplinary Interpretive Lens to Broaden Reflections on Alleviating Poverty and Promoting Decent Work. Frontiers in Psychology 7: 1-14.

Di Ruggiero E, Cohen J E, Cole D C (2014) The politics of agenda setting at the global level: key informant interviews regarding the International Labour Organization Decent Work Agenda. Globalization and Health 10: 56-71.

Drobnič S, Beham B and Praeg P (2010) Good Job, Good Life? Working Conditions and Quality of Life in Europe. Social Indicators Research 99(2): 205-225.

Duffy R D, Blustein D L, Diemer M A, Autin K L (2016) The Psychology of Working Theory. Journal of Counseling Psychology 63(2):127-48.

Duffy R D, Allan B A, England J W, Blustein D L, Autin K L, Douglass R P, Ferreira J, Santos E J R (2017) The Development and Initial Validation of the Decent Work Scale. Journal of Counseling Psychology 64(2): 206-21.

Erhel C, Guergoat-Larivière M (2016) Innovations and job quality regimes: a joint typology for the EU. hal-01907472. https://hal.archives-ouvertes.fr/hal-01907472

Esser I, Olsen K M (2012) Perceived Job Quality: Autonomy and Job Security within a Multi-Level Framework. European Sociological Review 28(4): 443-454.

European Foundation for the Improvement of Living and Working Conditions (2002) Quality of work and employment in Europe: issues and challenges. Luxembourg, Foundation Paper N.1, February 2002.

Eurofound (2012) Trends in Job Quality in Europe. Luxembourg, Publications Office of the European Union.

Eurofound (2017) Sixth European Working Conditions Survey - Overview report (2017 update), Publications Office of the European Union, Luxembourg. 
Eurofound (2019) Working conditions and workers health, Publications Office of the European Union, Luxembourg.

Eurofound (2020) European Working Conditions Survey Integrated Data File, 1991-2015. [data collection]. 8th Edition. UK Data Service. SN:7363. http://doi.org/10.5255/UKDA-SN-7363-8.

Eurofound, International Labour Organization (2019) Working conditions in a global perspective. Luxembourg and Geneva, Publications Office of the European Union and International Labour Organization.

European Parliament (2016) European Parliament Resolution on creating labour market conditions favourable for work-life balance (2016/2017(INI)).

Fana M, Milasi S, Napierala J, Fernandez Macias E, Gonzalez Vazquez I (2020) Telework, work organisation and job quality during the COVID-19 crisis: a qualitative study. Seville, European Commission, JRC122591.

Farne S, Vergara C A (2015) Economic growth, labour flexibilization and employment quality in Colombia, 2002-11. International Labour Review 154(2): 253-269.

Fehr E, Gächter S (2002) Fairness and retaliation: The economics of reciprocity. Journal of Economic Perspectives 14 (3): 159-181.

Felstead A, Gallie D, Green F, Henseke G (2019) Conceiving, Designing And Trailing A Short Form Measure Of Job Quality: A Proof Of Concept Study. Industrial Relations Journal 50 (1): 2-9.

Ferraro T, Pais L, Rebelo N, Dos Santos N, Moreira J M (2018) The Decent Work Questionnaire: Development and validation in two samples of knowledge workers. International Labour Review 157(2): 243-265.

Findlay P, Kalleberg, A L, Warhurst C (2013) The challenge of job quality. Human Relations, 66(4), 441-451.

Frey, B.S. and A. Stutzer (2005) Beyond Outcomes: Measuring Procedural Utility. Oxford Economic Papers 57, $90-111$.

Frey, D F, MacNaughton, G (2016) A Human Rights Lens on Full Employment and Decent Work in the 2030 Sustainable Development Agenda. Sage Open 6(2).

Gallie D (2007a). Production regimes and the quality of employment in Europe. Annual Review of Sociology 33: 85-104.

Gallie D (2007b). Production Regimes, Employment Regimes, and the Quality of Work. In Gallie D (ed) Employment Regimes and the Quality of Work. Oxford: Oxford University Press, p 1-34.

Gallie D (2007c) Task Discretion and Job Quality. In Gallie D (ed) Employment Regimes and the Quality of Work. Oxford, Oxford University Press, p 105-136.

Gallie D (2013a) Direct participation and the quality of work. Human Relations 66(4):453-73.

Gallie D, Ed (2013b) Economic Crisis, Quality of Work, and Social Integration. Oxford, Oxford University Press.

Gallie D, Zhou Y, Felstead A, Green F, Henseke G (2017) The implications of direct participation for organisational commitment, job satisfaction and affective psychological well-being: a longitudinal analysis. Industrial Relations Journal 48(2): 174-191.

Ghai D (2003) Decent work: concept and indicators. International Labour Review 142(2): 113-145. 
Gorman E H, Kmec J A (2007) We (Have To) Try Harder. Gender and Required Work Effort in Britain and the United States. Gender \& Society, 21(6), 828-856.

Graeber D (2013) On the phenomenon of bullshit jobs: a work rant. Strike (3): 1-13.

Graeber D (2019) Bullshit Jobs: A Theory. New York: Simon and Schuster.

Green C, Kler, P, Leeves G (2010) Flexible contract workers in inferior jobs: Reappraising the evidence. British Journal of Industrial Relations, 48, 605-629.

Green F (2004) Work Intensification, Discretion and the Decline in Well-Being at Work. Eastern Economic Journal 30(4):615-26.

Green F (2006) Demanding Work. The Paradox of Job Quality in the Affluent Economy. Woodstock, Princeton University Press.

Green F, Mostafa T, Parent-Thirion A, Vermeylen G, Van Houten G, Biletta I,, Lyly-Yrjanainen M (2013) Is Job Quality Becoming More Unequal? Industrial \& Labor Relations Review 66(4):753-84.

Green F, Felstead A, Gallie D, Henseke G (2021) Working Still Harder. Industrial and Labour Relations Review, online.

Grote G, Guest D (2017) The case for reinvigorating quality of working life research. Human Relations, 70(2): 149-167.

Häusser J A, Mojzisch A, Niesel M, Schulz-Hardt S (2010) Ten years on: A review of recent research on the Job Demand-Control (-Support) model and psychological well-being. Work \& Stress, 24(1): 135.

Holman D, McClelland C (2011) Job Quality in Growing and Declining Economic Sectors of the EU, University of Manchester, walqing working paper 2011.3.

Holman D (2013) Job types and job quality in Europe. Human Relations 66(4): 475-502.

Horowitz J (2016) Dimensions of Job Quality, Mechanisms, and Subjective Well-Being in the United States. Sociological Forum 31(2):419-40.

Hughes S, Haworth N (2011) Decent Work and Poverty Reduction Strategies. Relations IndustriellesIndustrial Relations 66(1): 34-53.

IABD (2017) Better Jobs Index: an employment conditions index for Latin America. Inter-American Development Bank. Technical Note 1326.

ILO (1999) Report of the Director-General: Decent Work. Geneva, International Labour Office.

ILO (2013) Decent Work Indicators. Guidelines for Producers and Users of Statistical and Legal Framework Indicators. 2nd Version. Geneva: International Labour Organization.

ILO, OECD. (2015) The Labour Share in G20 Economies: OECD.

Kalleberg, A L (2011) Good Jobs, Bad Jobs. New York Russell Sage Foundation.

Karasek R, Theorell, T. (1990) Healthy Work: Stress, Productivity, and the Reconstruction of Working Life. New York: Basic Books.

Lee S, McCann, D (eds) (2011). Regulating for Decent Work: New directions in labour market regulation. Basingstoke: Palgrave Macmillan; Geneva: International Labour Organization. 
Leschke J, Watt A (2008) Job quality in Europe. ETUI-REHSWorking Paper, No. 2008/07, www.etui.org/Publications2/Working-Papers/Job-quality-in-Europe

Marshall S (2013) Regulating For Decent Work: New Directions in Labour Market Regulation. Journal of Industrial Relations, 55(2): 304-306.

Masdonati J, Schreiber M, Marcionetti J, Rossier J (2019) Decent work in Switzerland: Context, conceptualization, and assessment. Journal of Vocational Behavior 100: 12-27.

Mira M C (2021) New Model for Measuring Job Quality: Developing an European Intrinsic Job Quality Index (EIJQI). Social Indicators Research, online.

Moen B E, Nyarubeli I P, Tungu A M, Ngowi A V, Kumie A, Deressa W, Mamuya S H D (2020) The Challenge of Obtaining a Decent Work Environment in Sub-Saharan Africa. In Ramutsindela $M$ and Mickler D (eds) Africa and the Sustainable Development Goals, p155-164.

Moktan A (2016) Decent Work Deficit In India. A Disaggregated Trend Over the Three Post-Reform Decades. World Review of Political Economy 7(4): 486-510.

Moktan A (2019) Is growth improving employment quality in India? Evidence of widening subnational inequality. Economic and Labour Relations Review 30(2): 285-306.

Muñoz de Bustillo R, Fernández-Macías E, Antón J-I, Esteve F (2011a) E pluribus unum? A critical survey of job quality indicators. Socio-Economic Review 9: 447-475.

Muñoz de Bustillo R, Fernández-Macías E, Antón J-I, Esteve F (2011b) Measuring More than Money: The Social Economics of Job Quality. Cheltenham, Edward Elgar.

Nikolova M, Cnossen F (2020) What makes work meaningful and why economists should care about it. Labour Economics 65, August, 101847.

OECD (2003) Employment Outlook: 2003 Towards More and Better Jobs. Paris, OECD.

OECD (2017) OECD Guidelines on Measuring the Quality of the Working Environment, OECD Publishing, Paris.

Okay-Somerville B, Scholarios D (2013) Shades of grey: Understanding job quality in emerging graduate occupations. Human Relations 66(4): 555-585.

Osterman P (2008) Improving the quality of low-wage work: The current American experience. International Labour Review, 147: 115-134.

Parkes K P, Mendham C A, von Rabenau C (1994) Social Support and the Demand-Discretion Model of Job Stress: Tests of Additive and Interactive Effects in Two Samples. Journal of Vocational Behavior, 44(1), 91-113.

Peels R, Fino M (2015) Pushed out the Door, Back in through the Window: The Role of the ILO in EU and US Trade Agreements in Facilitating the Decent Work Agenda. Global Labour Journal 6(2): 189202.

Piasna A, Burchell B, Sehnbruch K, Agloni N (2017) Job quality: conceptual and methodological challenges for comparative analysis. In: Grimshaw D, Fagan C, Hebson G, Tavora I (eds) Making Work More Equal. Manchester, Manchester University Press, p. 168-187.

Piasna A, Burchell B, Sehnbruch K (2019) Job quality in European employment policy: one step forward, two steps back? Transfer - European Review of Labour and Research 25(2): 165-180. 
Pollin R (2020) Green Economics and Decent Work: A Viable Unified Framework. Development and Change 51(2): 711-726.

Rosen S (1986) The Theory of Equalizing Differences. In Ashenfelter O C, Layard R Handbook of Labor Economics Volume 1, ed., Ch. 12. Amsterdam: Elsevier Science Publishers BV.

Sehnbruch K, González P, Apablaza M, Méndez R, Arriagada V (2020) The Quality of Employment (QoE) in nine Latin American countries: A multidimensional perspective. World Development, 127: 120.

Siegrist J (1996) Adverse health effects of high effort-low reward conditions at work. Journal of Occupational Health Psychology, 1: 27-43.

Siegrist J (2017) The Effort-Reward Imbalance Model. In Cooper C L, Quick J C. (Eds) The handbook of stress and health : a guide to research and practice. Chichester: Wiley-Blackwell .

Smith M, Burchell B, Fagan C, Obrien C (2008) Job quality in Europe. Industrial Relations Journal 39 (6): 586-603.

Spencer, D A (2015) Developing an understanding of meaningful work in economics: the case for a heterodox economics of work. Cambridge Journal of Economics 39: 675-688.

Stiglitz J, Sen A, Fitoussi J-P (2009) Report by the Commission on the Measurement of Economic Performance and Social Progress.

Storer A, Schneider D, Harknett K (2020) What Explains Racial/Ethnic Inequality in Job Quality in the Service Sector? American Sociological Review 85(4): 537-572.

Taylor, M (2017) Good Work: The Taylor Review of Modern Working Practices. London: Department for Business, Energy and Industrial Strategy.

Tortia, E.C. (2008) Worker Well-Being and Perceived Fairness: Survey-Based Findings from Italy. Journal of Socio-Economics 37, 2080- 2094.

UNECE (2015) Handbook on Measuring Quality of Employment. New York and Geneva, United Nations.

Venn D, Carey G, Strazdins L, Burgess, J (2016) What explains trends in Australian working-time arrangements in the 2000s? Labour \& Industry-a Journal of the Social and Economic Relations of Work, 26(2): 138-155.

Webster E, Budlender D, Orkin M (2015) Developing a diagnostic tool and policy instrument for the realization of decent work. International Labour Review, 154(2): 123-145.

World Health Organization (2007) Employment Conditions and Health Inequalities. Final Report to the Commission on Social Determinants of Health.

https://www.who.int/social determinants/resources/articles/emconet who report.pdf?ua=1

Yeoman R, Bailey C, Madden A, Thompson M (Eds.). (2019). The Oxford Handbook of Meaningful Work. Oxford: Oxford University Press.

Yu D (2020) Employment quality index for the South African labour market. Development Southern Africa 37(2): 276-294. 
Figure 1 Job Quality by GDP Per Capita Across European Countries, 2015
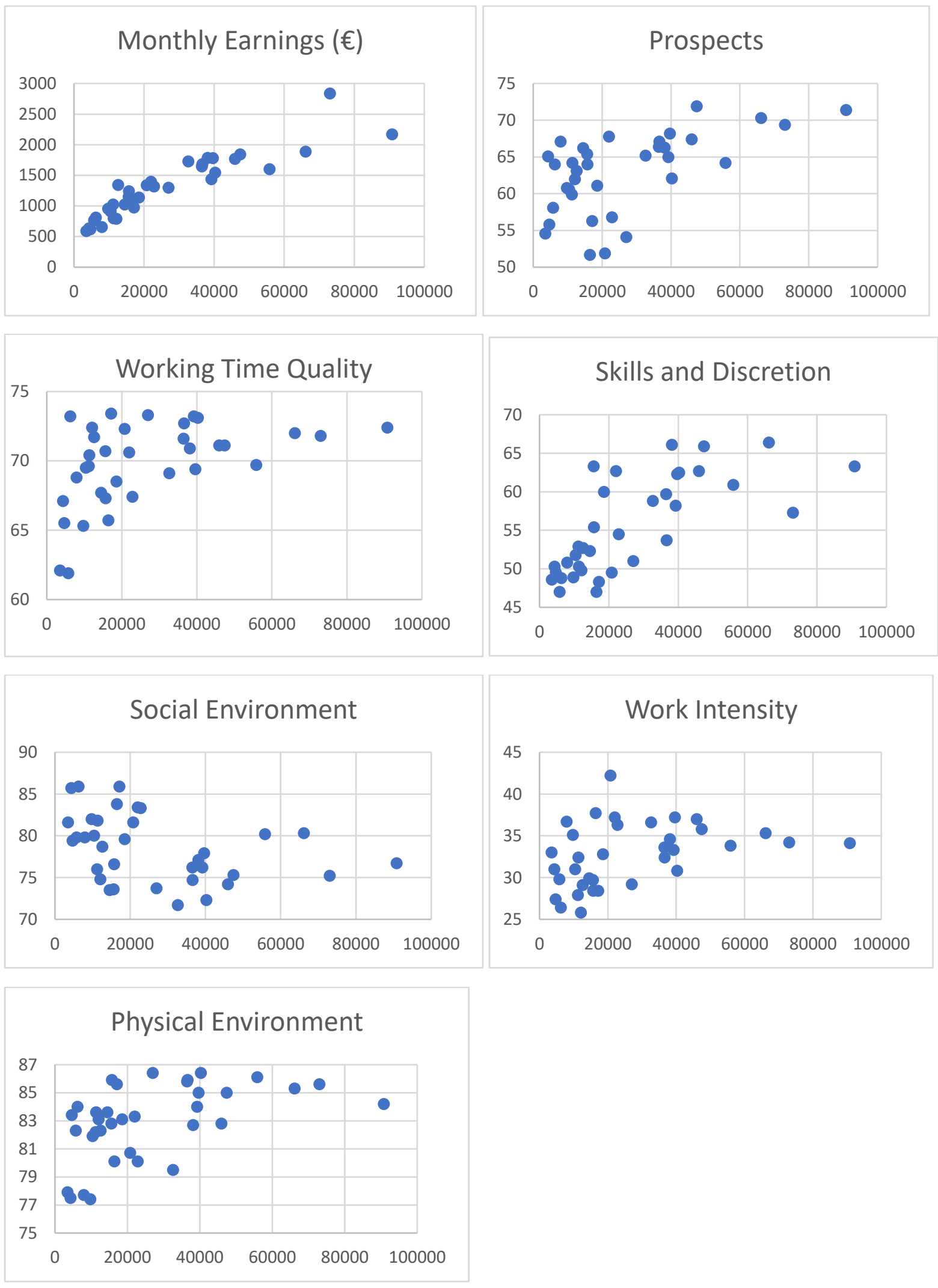

The $y$-axis is GDP per capita in Euros. The $x$-axes are the measures of average job quality in each domain, as given in Table 2. Work intensity is a negative indicator, while all other domains are positive indicators of job quality. 
Table 1 Quality of Work and Employment Frameworks.

\begin{tabular}{|c|c|c|c|c|c|c|}
\hline Institution and Concept & \multicolumn{5}{|c|}{ Unit of Analysis } & \multirow[t]{2}{*}{ Domains. } \\
\hline & Job & Person & Society & $\begin{array}{l}\text { Person- } \\
\text { job fit }\end{array}$ & $\begin{array}{l}\text { Labor } \\
\text { market }\end{array}$ & \\
\hline $\begin{array}{l}\text { International Labour } \\
\text { Office: } \\
\text { Decent Work }\end{array}$ & $\checkmark$ & $\checkmark$ & $\checkmark$ & & $\checkmark$ & $\begin{array}{l}\text { Employment opportunities, } \\
\text { earnings and productive } \\
\text { work, decent working time, } \\
\text { combining work, family and } \\
\text { personal life; unethical work; } \\
\text { security and stability of work; } \\
\text { equal opportunity and } \\
\text { treatment; safe work } \\
\text { environment; social security; } \\
\text { social dialogue (Anker 2003; } \\
\text { ILO, 2013). }\end{array}$ \\
\hline $\begin{array}{l}\text { European Union: } \\
\text { Job Quality }\end{array}$ & $\checkmark$ & & & & & $\begin{array}{l}\text { Earnings, Prospects, Working } \\
\text { Time Quality, Work Intensity, } \\
\text { Physical Environment, Skills } \\
\text { and Discretion, Social } \\
\text { Environment. (Eurofound, } \\
\text { 2012; European Parliament, } \\
\text { 2016; General Principles 46) }\end{array}$ \\
\hline $\begin{array}{l}\text { OECD: } \\
\text { Quality of Work } \\
\text { Environment }\end{array}$ & $\checkmark$ & & $\checkmark$ & & & $\begin{array}{l}\text { Earnings Quality, Labor } \\
\text { Market Security, Quality of } \\
\text { Working Environment (Cazes } \\
\text { et al. 2015) }\end{array}$ \\
\hline $\begin{array}{l}\text { United Nations } \\
\text { Economic Commission } \\
\text { for Europe: } \\
\text { Quality of Employment }\end{array}$ & $\checkmark$ & $\checkmark$ & & $\checkmark$ & & $\begin{array}{l}\text { Safety and Ethics, Pay and } \\
\text { Benefits, Working Time } \\
\text { Quality, Security \& Social } \\
\text { Protection, Social Dialogue, } \\
\text { Skills, Working Relationships } \\
\text { and Motivation (United } \\
\text { Nations Economic } \\
\text { Commission for Europe 2015) }\end{array}$ \\
\hline $\begin{array}{l}\text { European Trades Union } \\
\text { Institute: } \\
\text { Job Quality }\end{array}$ & $\checkmark$ & & & $\checkmark$ & & $\begin{array}{l}\text { Wages, job security, working } \\
\text { time quality, hours fit, work } \\
\text { intensity, autonomy, physical } \\
\text { working conditions, skills and } \\
\text { career development, } \\
\text { collective representation } \\
\text { (Leschke and Watt 2008) }\end{array}$ \\
\hline
\end{tabular}


Table 2 Average Job Quality Indices, European Countries, 2015.

\begin{tabular}{|c|c|c|c|c|c|c|c|}
\hline Albania & 590 & 54.6 & 62.1 & 33.0 & 48.6 & 81.6 & 77.9 \\
\hline Austria & 1440 & 65.0 & 73.2 & 33.3 & 58.2 & 76.2 & 84.0 \\
\hline Belgium & 1649 & 66.4 & 72.0 & 33.6 & 60.0 & 76.2 & 85.8 \\
\hline Bulgaria & 811 & 64.0 & 73.0 & 26.4 & 49.0 & 85.9 & 84.0 \\
\hline Croatia & 914 & 60.6 & 69.5 & 31.0 & 51.8 & 80.0 & 81.9 \\
\hline Cyprus & 1340 & 51.9 & 72.3 & 42.2 & 49.5 & 81.6 & 80.7 \\
\hline Czech Republic & 1243 & 64.0 & 67.3 & 28.4 & 55.4 & 76.6 & 85.9 \\
\hline Denmark & 1845 & 71.9 & 71.1 & 35.8 & 65.9 & 75.3 & 85.0 \\
\hline Estonia & 1152 & 65.4 & 70.7 & 29.7 & 63.3 & 73.6 & 82.8 \\
\hline Finland & 1786 & 66.3 & 70.9 & 34.6 & 66.1 & 77.1 & 82.7 \\
\hline France & 1728 & 65.2 & 69.1 & 36.6 & 58.8 & 71.7 & 79.5 \\
\hline FYROM & 638 & 65.1 & 67.1 & 31.0 & 50.3 & 85.7 & 77.5 \\
\hline Germany & 1685 & 67.1 & 72.7 & 32.4 & 53.7 & 74.7 & 85.9 \\
\hline Greece & 1032 & 51.7 & 65.7 & 37.7 & 47.0 & 83.8 & 80.1 \\
\hline Hungary & 798 & 64.2 & 70.4 & 32.4 & 50.3 & 81.8 & 83.6 \\
\hline Ireland & 1602 & 64.2 & 69.7 & 33.8 & 60.9 & 80.2 & 86.1 \\
\hline Italy & 1301 & 54.1 & 73.3 & 29.2 & 51.0 & 73.7 & 86.4 \\
\hline Latvia & 790 & 62.0 & 72.4 & 25.8 & 49.8 & 74.8 & 83.1 \\
\hline Lithuania & 1346 & 63.1 & 71.7 & 29.1 & 52.7 & 78.7 & 82.3 \\
\hline Luxembourg & 2172 & 71.4 & 72.4 & 34.1 & 63.3 & 76.7 & 84.2 \\
\hline Malta & 1397 & 67.8 & 70.6 & 37.2 & 62.7 & 83.4 & 83.3 \\
\hline Montenegro & 766 & 58.1 & 61.9 & 29.8 & 47.0 & 79.8 & 82.3 \\
\hline Netherlands & 1544 & 62.1 & 73.1 & 30.8 & 62.5 & 72.3 & 86.4 \\
\hline Norway & 1887 & 70.3 & 72.0 & 35.3 & 66.4 & 80.3 & 85.3 \\
\hline Poland & 1025 & 59.9 & 69.6 & 27.9 & 52.9 & 76.0 & 82.2 \\
\hline Portugal & 974 & 56.3 & 73.4 & 28.4 & 48.3 & 85.9 & 85.6 \\
\hline Romania & 657 & 67.1 & 68.8 & 36.7 & 50.8 & 79.8 & 77.7 \\
\hline Serbia & 621 & 55.8 & 65.5 & 27.4 & 49.5 & 79.4 & 83.4 \\
\hline Slovakia & 1026 & 66.2 & 67.7 & 29.9 & 52.3 & 73.5 & 83.6 \\
\hline Slovenia & 1141 & 61.1 & 68.5 & 32.8 & 60.0 & 79.6 & 83.1 \\
\hline Spain & 1321 & 56.8 & 67.4 & 36.3 & 54.5 & 83.3 & 80.1 \\
\hline Sweden & 1771 & 67.4 & 71.1 & 37.0 & 62.7 & 74.2 & 82.8 \\
\hline Switzerland & 2838 & 69.4 & 71.8 & 34.2 & 57.3 & 75.2 & 85.6 \\
\hline Turkey & 956 & 60.8 & 65.3 & 35.1 & 48.9 & 82.0 & 77.4 \\
\hline United Kingdom & 1784 & 68.2 & 69.4 & 37.2 & 62.3 & 77.9 & 85.0 \\
\hline EU28 & 1487.0 & 63.4 & 70.6 & 33.3 & 55.9 & 76.5 & 83.6 \\
\hline All & 1440.7 & 63.2 & 70.0 & 33.5 & 55.2 & 77.1 & 83.0 \\
\hline sd (all) & 996.0 & 19.7 & 14.6 & 18.6 & 21.0 & 23.2 & 15.1 \\
\hline
\end{tabular}




\begin{tabular}{|r|c|c|c|c|c|c|c|}
\hline Table 2 (Continued) & & & & & & & \\
\hline $\begin{array}{l}\text { Association with job } \\
\text { satisfaction:* }\end{array}$ & & & & & & & \\
Bivariate & 0.13 & 0.31 & 0.18 & -0.24 & 0.26 & 0.34 & 0.22 \\
\hline Multivariate & 0.03 & 0.20 & 0.08 & -0.17 & 0.15 & 0.22 & 0.07 \\
\hline
\end{tabular}

Data Source: European Working Conditions Survey 2015, author's analysis from integrated data set (Eurofound 2020). The indices are the same as those used and explained in Eurofound's 6th EWCS overview report (Eurofound 2017). Notes: Monthly earnings are in Euros; all other indices are constructed to range in principle from 1-100.

*Estimates are the standardized marginal effects from an OLS regression of 'Satisfaction with Working Conditions' on each job quality index. The multivariate model includes all job quality domains but no other variables. All coefficients are statistically significant at the $1 \%$ level. The total variance in satisfaction accounted for in this multivariate model across the whole sample is 0.26 . 
Table 3 Inequality in Job Quality Domains, European Countries, 2015.

Difference between the median and the $10^{\text {th }}$ percentile, by job quality indicator.

\begin{tabular}{|c|c|c|c|c|c|c|c|}
\hline & $\begin{array}{c}\text { Log } \\
\text { Monthly } \\
\text { Earnings }\end{array}$ & $\begin{array}{c}\text { Pro- } \\
\text { spects }\end{array}$ & $\begin{array}{c}\text { Working } \\
\text { Time } \\
\text { Quality }\end{array}$ & $\begin{array}{l}\text { Work In- } \\
\text { tensity }\end{array}$ & $\begin{array}{l}\text { Skills } \\
\text { and Dis- } \\
\text { cretion }\end{array}$ & $\begin{array}{c}\text { Social } \\
\text { Environ- } \\
\text { ment }\end{array}$ & $\begin{array}{c}\text { Physical } \\
\text { Environ- } \\
\text { ment }\end{array}$ \\
\hline Albania & 0.69 & 31.3 & 23.8 & 22.5 & 25.8 & 37.5 & 23.1 \\
\hline Austria & 0.92 & 31.3 & 24.0 & 27.8 & 32.2 & 53.5 & 26.9 \\
\hline Belgium & 0.53 & 25.0 & 24.2 & 29.4 & 35.2 & 51.4 & 21.8 \\
\hline Bulgaria & 0.48 & 31.3 & 23.5 & 25.2 & 37.2 & 29.2 & 25.6 \\
\hline Croatia & 0.80 & 29.2 & 26.7 & 30.3 & 32.2 & 36.1 & 24.4 \\
\hline Cyprus & 0.69 & 25.0 & 20.3 & 26.6 & 28.5 & 50.0 & 28.2 \\
\hline Czech Republic & 0.72 & 29.2 & 27.7 & 24.2 & 32.0 & 47.2 & 20.5 \\
\hline Denmark & 1.56 & 25.0 & 23.7 & 26.7 & 25.5 & 51.4 & 15.4 \\
\hline Estonia & 0.78 & 25.0 & 23.0 & 23.8 & 31.3 & 52.8 & 23.1 \\
\hline Finland & 0.69 & 25.0 & 24.5 & 26.7 & 27.1 & 51.4 & 21.8 \\
\hline France & 0.69 & 29.2 & 23.7 & 31.7 & 32.2 & 54.2 & 28.2 \\
\hline FYROM & 0.69 & 33.3 & 24.2 & 25.8 & 29.6 & 42.4 & 30.8 \\
\hline Germany & 1.18 & 25.0 & 21.1 & 27.4 & 33.6 & 46.5 & 19.2 \\
\hline Greece & 0.98 & 25.0 & 29.2 & 23.1 & 33.3 & 38.2 & 25.6 \\
\hline Hungary & 0.79 & 18.8 & 25.3 & 23.2 & 33.7 & 37.5 & 25.6 \\
\hline Ireland & 0.95 & 29.2 & 27.9 & 31.7 & 30.6 & 53.5 & 23.1 \\
\hline Italy & 0.96 & 31.3 & 21.2 & 24.5 & 32.9 & 28.5 & 24.4 \\
\hline Latvia & 0.65 & 29.2 & 26.0 & 24.6 & 28.6 & 52.1 & 26.9 \\
\hline Lithuania & 0.61 & 18.8 & 24.7 & 23.9 & 30.8 & 51.4 & 25.6 \\
\hline Luxembourg & 0.65 & 25.0 & 22.9 & 27.7 & 33.0 & 55.6 & 24.4 \\
\hline Malta & 0.60 & 27.1 & 24.0 & 28.1 & 21.9 & 49.3 & 25.6 \\
\hline Montenegro & 0.56 & 33.3 & 26.1 & 26.5 & 28.2 & 37.5 & 24.4 \\
\hline Netherlands & 1.42 & 25.0 & 24.0 & 28.9 & 34.2 & 50.0 & 20.5 \\
\hline Norway & 0.88 & 25.0 & 20.8 & 26.5 & 24.2 & 49.3 & 16.7 \\
\hline Poland & 0.69 & 29.2 & 25.0 & 25.9 & 31.7 & 38.9 & 28.2 \\
\hline Portugal & 0.77 & 25.0 & 24.7 & 24.7 & 28.3 & 21.5 & 19.2 \\
\hline Romania & 0.47 & 25.0 & 24.1 & 18.2 & 27.6 & 49.3 & 25.6 \\
\hline Serbia & 0.92 & 31.3 & 28.9 & 29.6 & 30.8 & 36.1 & 24.4 \\
\hline Slovakia & 0.51 & 25.0 & 25.7 & 26.9 & 31.8 & 50.0 & 24.4 \\
\hline Slovenia & 0.47 & 29.2 & 26.2 & 29.9 & 33.8 & 50.7 & 23.1 \\
\hline Spain & 0.79 & 31.3 & 22.4 & 28.9 & 32.5 & 39.6 & 26.9 \\
\hline Sweden & 0.74 & 25.0 & 22.1 & 26.2 & 28.3 & 52.1 & 21.8 \\
\hline Switzerland & 1.05 & 25.0 & 22.7 & 28.5 & 30.5 & 50.0 & 20.5 \\
\hline Turkey & 1.10 & 29.2 & 24.2 & 22.5 & 29.9 & 37.5 & 30.8 \\
\hline United Kingdom & 1.03 & 25.0 & 28.0 & 27.6 & 35.6 & 50.7 & 23.1 \\
\hline
\end{tabular}


Table 4 The Gender Gap in Job Quality Domains, European Countries, 2015.

Difference between female and male job quality indicators.

\begin{tabular}{|c|c|c|c|c|c|c|c|}
\hline & $\begin{array}{c}\text { Log } \\
\text { Monthly } \\
\text { Earnings }\end{array}$ & $\begin{array}{l}\text { Pro- } \\
\text { spects }\end{array}$ & $\begin{array}{l}\text { Working } \\
\text { Time } \\
\text { Quality }\end{array}$ & $\begin{array}{l}\text { Work In- } \\
\text { tensity }\end{array}$ & $\begin{array}{l}\text { Skills } \\
\text { and Dis- } \\
\text { cretion }\end{array}$ & $\begin{array}{c}\text { Social } \\
\text { Environ- } \\
\text { ment }\end{array}$ & $\begin{array}{c}\text { Physical } \\
\text { Environ- } \\
\text { ment }\end{array}$ \\
\hline Albania & $-0.20 *$ & $3.69 *$ & $5.68^{*}$ & 1.91 & -0.72 & 0.72 & $2.82^{*}$ \\
\hline Austria & $-0.40^{*}$ & -0.96 & $5.03^{*}$ & $-4.38^{*}$ & $-3.95^{*}$ & -1.14 & $5.01 *$ \\
\hline Belgium & $-0.18^{*}$ & -0.30 & $3.33^{*}$ & -0.67 & -1.00 & $-3.60 *$ & $3.45^{*}$ \\
\hline Bulgaria & $-0.22 *$ & $3.60 *$ & $3.76^{*}$ & -1.66 & -0.23 & 0.70 & $8.15^{*}$ \\
\hline Croatia & $-0.13^{*}$ & -1.32 & $3.97^{*}$ & 1.08 & 0.22 & -0.82 & $6.67^{*}$ \\
\hline Cyprus & $-0.21 *$ & 1.52 & $3.27^{*}$ & 0.71 & 0.88 & 0.09 & $8.32 *$ \\
\hline Czech Republic & $-0.43 *$ & $-3.43^{*}$ & $5.98^{*}$ & $-3.36^{*}$ & -1.65 & -2.51 & $6.40 *$ \\
\hline Denmark & $-0.15^{*}$ & -2.11 & 1.15 & $6.12^{*}$ & 0.64 & $-3.91^{*}$ & 0.27 \\
\hline Estonia & $-0.40 *$ & 1.16 & $3.68 *$ & $-2.50 *$ & $2.61^{*}$ & 1.65 & $6.74 *$ \\
\hline Finland & $-0.26 *$ & -0.81 & $1.98^{*}$ & $4.54^{*}$ & -1.06 & $-5.01^{*}$ & $4.15^{*}$ \\
\hline France & $-0.26 *$ & $-2.53^{*}$ & $1.93 *$ & 0.50 & $-2.96^{*}$ & $-3.48^{*}$ & $5.86 *$ \\
\hline FYROM & -0.03 & 2.15 & $5.25^{*}$ & -0.66 & -1.22 & 0.28 & $8.00 *$ \\
\hline Germany & $-0.45^{*}$ & $-2.62^{*}$ & $3.70 *$ & -0.80 & -1.49 & -1.56 & $5.25^{*}$ \\
\hline Greece & $-0.24 *$ & -2.39 & $5.70^{*}$ & -0.91 & $-5.26 *$ & $-3.13^{*}$ & $8.26 *$ \\
\hline Hungary & $-0.12 *$ & 0.75 & $3.51^{*}$ & -1.95 & $3.17 *$ & -0.86 & $7.75^{*}$ \\
\hline Ireland & $-0.30 *$ & 1.21 & $6.66^{*}$ & 1.50 & -1.76 & -0.33 & $4.40 *$ \\
\hline Italy & $-0.29 *$ & $-2.84^{*}$ & $3.71^{*}$ & $-2.49 *$ & -1.46 & 0.95 & $5.50 *$ \\
\hline Latvia & $-0.35^{*}$ & 0.64 & $3.12 *$ & -0.96 & 0.55 & -2.07 & $6.96 *$ \\
\hline Lithuania & $-0.32 *$ & -2.37 & $2.06^{*}$ & -1.81 & 0.23 & 0.47 & $8.91 *$ \\
\hline Luxembourg & $-0.34 *$ & -1.10 & $3.11 *$ & -0.38 & $-3.40^{*}$ & $-3.99 *$ & $3.44 *$ \\
\hline Malta & $-0.23 *$ & 2.06 & $4.96 *$ & 2.00 & 1.00 & 0.40 & $5.62 *$ \\
\hline Montenegro & $-0.20 *$ & 0.30 & $4.92 *$ & 0.46 & -0.28 & -0.83 & $6.83^{*}$ \\
\hline Netherlands & $-0.43 *$ & $-2.59 *$ & $3.70 *$ & 1.04 & $-2.55^{*}$ & -3.01 & $2.41 *$ \\
\hline Norway & $-0.36 *$ & 0.02 & $3.20 *$ & 2.04 & $-2.23^{*}$ & -1.18 & $1.55^{*}$ \\
\hline Poland & $-0.21^{*}$ & -0.15 & $5.15^{*}$ & $-2.03 *$ & 1.82 & 0.91 & $10.49 *$ \\
\hline Portugal & $-0.19 *$ & -1.74 & $3.02 *$ & $-2.25^{*}$ & -2.31 & -0.27 & $2.94^{*}$ \\
\hline Romania & $-0.16^{*}$ & 1.30 & $3.03 *$ & 1.51 & -0.05 & -0.09 & $5.76^{*}$ \\
\hline Serbia & $-0.19 *$ & -0.49 & $4.80^{*}$ & -0.83 & -1.82 & -0.20 & $9.03 *$ \\
\hline Slovakia & $-0.30 *$ & -0.95 & $4.26 *$ & 0.90 & $-2.80 *$ & -2.44 & $5.22 *$ \\
\hline Slovenia & $-0.14 *$ & -0.45 & $3.63 *$ & 0.72 & 1.30 & $-2.57^{*}$ & $5.32 *$ \\
\hline Spain & $-0.32 *$ & -0.78 & $3.37^{*}$ & $-1.46^{*}$ & $-1.92^{*}$ & 0.38 & $6.71^{*}$ \\
\hline Sweden & $-0.17^{*}$ & -1.16 & $1.74 *$ & $4.20 *$ & -1.75 & $-4.03 *$ & $1.76^{*}$ \\
\hline Switzerland & $-0.38 *$ & -2.17 & $3.66^{*}$ & $-3.21^{*}$ & -2.39 & -1.16 & $5.36 *$ \\
\hline Turkey & $-0.21^{*}$ & -0.89 & $5.92 *$ & 1.05 & -0.82 & 0.97 & $5.57^{*}$ \\
\hline United Kingdom & $-0.41 *$ & 1.63 & $3.91 *$ & 1.03 & 0.65 & 0.69 & $4.29 *$ \\
\hline
\end{tabular}

Notes: see Table 2.

\footnotetext{
${ }^{1}$ I am very grateful to Brendan Burchell, Alan Felstead, Uwe Jirjahn, Arne Kalleberg, Kirsten Sehnbruch and Frances Stewart, all of whom generously read and commented most helpfully on an earlier draft of this review.
} 